\title{
Pollution of Freshwater Coelatura species (Mollusca: Bivalvia: Unionidae) with Heavy Metals and its impact on the Ecosystem of the River Nile in Egypt
}

Faiza M El Assal*, Salwa F Sabet, Kohar G Varjabedian and Mona F Fol

Department of Zoology, Faculty of Science, Cairo University, Giza, Egypt

\begin{abstract}
The Knowledge of heavy metal concentrations in aquatic species is important with respect to genetic variation and extinction of some species and loss of biodiversity in the ecosystem of rivers and lakes. We used random amplified polymorphic DNA-polymerase chain reaction (RAPD-PCR) to examine genetic differentiation among Coelatura species collected from the River Nile, at two polluted locations (El-Kanater, Qalyoubyia governorate and Tura, Cairo governorate, Egypt) and the impact of heavy metal pollution on the genetic structure of these species (C. aegyptiaca, C. prasidens, C. canopicus, C. gaillardoti and C. parreyssi). RAPD PCR was carried out using five random primers (UBC 476, UBC 477, UBC 478, UBC 479 and UBC 487) that provided strong amplifications. The RAPD- PCR analysis between any given pair of species, based on the number of bands, showed natural differences or polymorphism among the Coelatura species under investigation. The greatest number of PCR fragments was found with primers UBC 478 and UBC 479 (6-7 bands), while less fragments were obtained with primers UBC 476, UBC 477 and UBC 487 (2-4 bands)

Primers UBC 477 and UBC 479 clearly distinguished the five studied Coelatura species into only three species, C. aegyptiaca, C. parreyssi and C. canopicus and primer UBC 478 showed DNA alteration concerning C. parreyssi, C. gaillardoti and C. canopicus.

Genetic diversity was also measured as the percentage of polymorphic bands for each primer.

The dendograms and the similarity index (D) showed, also, that the five studied species could be classified into only three species, C. aegyptiaca, C. canopicus and C. parreyssi

The concentration of six heavy metals (copper, cobalt, nickel, manganese, lead and iron) was determined in the soft parts of the Coelatura species to assess the impact of heavy metal pollution on their genetic variation. Metal concentrations in the tissues were found to be higher than the permissible limits, indicating that heavy metals might play an important role in the genetic variation of Coelatura species by inducing DNA damage and alteration of the genetic pattern as well as they may be the cause of the extinction of some species and the loss of biodiversity in the ecosystem of the freshwater ecosystem.
\end{abstract}

Keywords: Coelatura; C. aegyptiac;, C. prasidens; C. canopicus; C. gaillardoti; C. parreyssi; Taxonomy, RAPD-PC; Genetic variation; Heavy metals; Pollution

\section{Introduction}

Pollution of the freshwater environments by heavy metals due to increased action of flowing out discharge from various industries has received considerable attention in that it is able to influence freshwater organisms, leading to modify their genetic diversity [1-7]. Pollution affects adversely organisms and could be the cause of the genetic variation of some species.

Metal exposure was found to lead to various types of DNA damages and alteration of genetic patterns within populations [8,9] and also, DNA damage may indicate levels of metal toxicity.

In Egypt, Coelatura species showed great argument on their taxonomy, and their number ranged from 1 to 14 species in various studies [10-12] which consequently lead to questionable taxonomy. Therefore, in the present study, we used RAPD-PCR method to resolve the conflict on the taxonomical status of some Coelatura species from the River Nile in Egypt and to discuss the effect of metal pollution in this respect.

On the other hand, Unionidae are declining at a catastrophic rate worldwide. They are threatened by a number of factors among which industrial and human activities inducing environmental pollution [13], pointing toward impending mass extinction. The significant loss of biodiversity may permanently alter ecosystem functioning in rivers and lakes as well as alter the rate of ecological processes [14].

Metal pollution of freshwater sources appears to be the main cause of the endangerment of freshwater mussels which are endangered nowadays worldwide and it is possible that high amounts of metals are toxic and could be a contributing threatening factor [15]. Therefore, it is important to estimate the accurate levels of trace elements in some mussels' species (Coelatura species as example) to assess the impact of heavy metals on their genetic variation and on the loss of biodiversity in the ecosystem of the River Nile in Egypt.

*Corresponding author: Faiza M El Assal, Department of Zoology, Faculty of Science, Cairo University, Giza, Egypt, 12613, Tel: +20-235676105; E-mail: faizaelassal@yahoo.com

Received August 04, 2014; Accepted December 17, 2014; Published December 22, 2014

Citation: El Assal FM, Sabet SF, Varjabedian KG, Fol MF (2014) Pollution of Freshwater Coelatura species (Mollusca: Bivalvia: Unionidae) with Heavy Metals and its impact on the Ecosystem of the River Nile in Egypt. Int J Waste Resources 4: 163. doi: 10.4172/2252-5211.1000163

Copyright: (c $2014 \mathrm{El}$ Assal FM, et al. This is an open-access article distributed under the terms of the Creative Commons Attribution License, which permits unrestricted use, distribution, and reproduction in any medium, provided the original author and source are credited. 
Citation: El Assal FM, Sabet SF, Varjabedian KG, Fol MF (2014) Pollution of Freshwater Coelatura species (Mollusca: Bivalvia: Unionidae) with Heavy Metals and its impact on the Ecosystem of the River Nile in Egypt. Int J Waste Resources 4: 163. doi: 10.4172/2252-5211.1000163

Page 2 of 11

\section{Material and Methods}

\section{Collections of samples}

The Coelatura species (C. aegyptiaca, C. prasidens, C. gaillardoti, C. canopicus and C. parreyssi) were collected from the River Nile at two localities, known to be heavy metal polluted (El-Kanater, Qalyoubia Governorate and Tura, Cairo Governorate). Samples were monthly and randomly collected, for one year, from September 2009 to August 2010, then transported to the laboratory, sorted and maintained under the same conditions of food and temperature

\section{Genetic study}

DNA extraction and RAPD-PCR analysis: Samples of the Coelatura species were dissected and their soft parts were preserved in $100 \%$ ethyl alcohol at $-20^{\circ} \mathrm{C}$ until used. Total genomic DNA was extracted from frozen ethanol-preserved mantle using Qiagen Dneasy tissue kit (Valencia, CA, USA) according to the manufacturer's manual. Seven primers were used in the present work, which were previously used in the bivalve RAPD-PCR [11,16,17].

$$
\begin{aligned}
& \text { 476: } 5 \text { ' - TTG AGG CCC T - 3’ } \\
& \text { 477: } 5 \text { '-TGT TGT GCC C - 3` } \\
& \text { 478: } 5{ }^{`} \text { - CGA GCT GGT C - } 3 \\
& \text { 479: } 5^{`} \text { - CTC ATA CGC G - } 3 \text { ’ } \\
& \text { 483: } 5 \text { ' - GCA CTA AGA C- } 3^{\prime} \\
& \text { 486: } 5 \text { ` - CCA GCA TCA G - } 3 \text { ` } \\
& \text { 487: } 5 \text { ` - GTG GCT AGG T - 3` }
\end{aligned}
$$

Only five primers worked out (UBC 476, UBC 477, UBC 478, UBC 479 and UBC 487). Amplifications were performed by modifying the protocol reported by Williams et al (1990) [18]. The $25 \mu \mathrm{l}$ mixture contained $25 \mathrm{ng}$ of template DNA, 1.5 unit of Taq Polymerase, 10 mMdNTPs, $10 \mathrm{pM}$ primer, and $2.5 \mu \mathrm{l}$ of 10x PCR buffer. (Dream Taq Green PCR MasterMix (2X) (Fermentas). Each amplification reaction was performed using a single primer and repeated twice to verify band autosimilarity [19].

Amplifications were performed in T-personal thermal cycler (Techne, TC-3000G), programmed for 45 cycles of $94^{\circ} \mathrm{C}$ for 1 minutes., $35^{\circ} \mathrm{C}$ for 1 minute., and $72^{\circ} \mathrm{C}$ for 1 minute. An initial denaturation step ( 3 minutes, $94^{\circ} \mathrm{C}$ ) and a final extension holding $\left(10\right.$ minutes, $\left.72^{\circ} \mathrm{C}\right)$ were included in the first and last cycles, respectively.

Ten $\mu \mathrm{l}$ of the reaction products were resolved by $2 \%$ agarose gel electrophoresis at 85 volt in $1 \mathrm{x}$ TAE (Tris-acetate-EDTA) buffer. The gel was stained with ethidium bromide and photographed by a digital camera under UV transilluminator. For the comparison of the amplified products, population-specific fragments were detected using Gene Ruler 1 kb Plus DNA Ladder from Fermentas.

Molecular data analysis: Molecular data analysis was carried out using gel documentation system (SynGene, GeneTools - File version: 4.02.03, France), for the dendogram and calculation of similarity index of each primer between the studied Coelatura species. RAPD amplification products were scored as $0 / 1$ for absence / presence of homologous bands [20] and analyses carried out using the NTSYS PC2.0 software [21].

Similarity coefficient matrix was calculated using Jaccard similarity algorithm [22] for RAPD markers. Dendograms were constructed using the UPGMA method, Unweighed pair-Group Method with arithmetical algorithms Averages [23]. Genetic diversity was also measured as the percentage of polymorphic bands. The percentage of polymorphic RAPD loci was calculated for each species, as well as the mean and overall value for all species and each primer.

\section{Heavy metal analysis}

Water and sediment analysis: Water and sediment samples collected from the two studied regions were analysed to determine the concentrations of heavy metals, using atomic absorption spectrophotometer model A-Analyst 100 Perkin Elmer. Metals analysed were Copper $(\mathrm{Cu})$, Cobalt $(\mathrm{Co})$, Nickel $(\mathrm{Ni})$, Manganese $(\mathrm{Mn})$, Lead $(\mathrm{Pb})$, and Iron $(\mathrm{Fe})$.

Tissue analysis [24]: Mussels were dissected and the soft parts were excised on clean tared pieces of plastic. Wet weights were then determined by the method of Johanson et al. [25]. Tissues were dried to constant weight, at room temperature, for 24 hours, removed from the plastic pieces and placed in $1.5 \mathrm{ml}$ washed micro centrifuge tubes.

To each tube, $5 \mathrm{ml}$ of piperidine (mole/litre) was added, the tubes were then cooled to room temperature, after which $2 \mathrm{ml}$ of $61 \%(\mathrm{~V} / \mathrm{V})$ $\mathrm{HCLO}_{4}$ was added to the precipitate. After 10 minutes, $7 \mathrm{ml}$ of deionized water was added and mixed. Fifteen minutes later, the tubes were centrifuged for one minute, at 10,000 r.p.m. in a microcentrifuge (Beck Man/ Model J-2, 21). Supernatants were added in aliquots for analysis; using an atomic absorption spectrophotometer, model A-Analyst 100 Perkin Elmer instrumentation laboratories.

Single cuvette attached to an aspiration pump was used to minimize handling of samples and absorption of each ion was integrated for 2 seconds. Metals measured in tissues were $\mathrm{Cu}, \mathrm{Co}, \mathrm{Ni}, \mathrm{Mn}, \mathrm{Pb}$ and $\mathrm{Fe}$.

The transfer factor (TF) in mussel tissues from the aquatic ecosystem, which include water and sediments, was calculated according to Kalfakakour and Akrida-Demertzi [26] and Rashed [27] as follows:

\section{$\mathrm{TF}=$ Mtissue/ Msediment or Mwater}

Mtissue $=$ the metal concentration in mussel tissue, Msediment $=$ the metal concentration in sediment and Mwater $=$ the metal concentration in water.

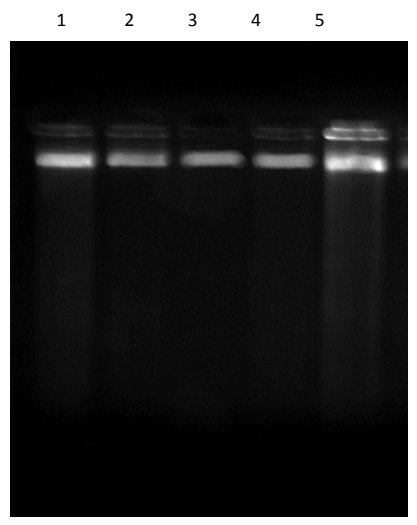

Figure 1: Agrose gel of extracted DNA from the mantle of the five Coelatura species under investigation.

1. C. parreyssi

2. C. aegyptiaca

3. C. gaillardoti

4. C. canopicus

5. C. prasidens 
Citation: El Assal FM, Sabet SF, Varjabedian KG, Fol MF (2014) Pollution of Freshwater Coelatura species (Mollusca: Bivalvia: Unionidae) with Heavy Metals and its impact on the Ecosystem of the River Nile in Egypt. Int J Waste Resources 4: 163. doi: 10.4172/2252-5211.1000163

Page 3 of 11

\section{Statistical analysis}

A software computer program SPSS Version 19 was used to test the significance differences between mean values of the different parameters in the studied mussels. One - way ANOVA and MANOVA were employed to find the difference in the ecological analysis at a probability level $\mathrm{P}>0.05$ for insignificant results and $\mathrm{P}<0.05$ and $\mathrm{P}<0.0001$ for significant results.

\section{Results}

\section{Genetic studies}

Individual amplifications of agarose gel extracted DNA from the mantle of the five studied Coelatura species (Figure 1) were performed using the five primers UBC 476, UBC 477, UBC 478, UBC 479 and UBC 487, in order to determine the genetic relationship between them.

RAPD PCR carried out using the five primers provided strongly amplified fragments (Figures 2-6).

Genetic variability was observed among the studied Coelatura species. The greatest number of PCR fragments was found with primers UBC 478 and UBC 479 (6-7 bands), while less fragments were obtained with primers UBC 476, UBC 477 and UBC 487 (2-4 bands). The RAPD- PCR analysis was based on the number of bands that were different between any given pair of species (Table 1). Analyses showed natural differences (polymorphism) among Coelatura species under investigation.

Primers UBC 477 (Figure 3a) and UBC 479 (Figure 5a) gave monomorphic bands with C. Parreyssi and C. gaillardoti and as well as with C. aegyptiaca and C. prasidens. While, C. canopicus revealed some polymorphic bands (Figures $3 \mathrm{a}$ and $5 \mathrm{a}$ ). Primer UBC 476 gave similar results for $C$. aegyptiaca and C. prasidens as with primers UBC 477 and UBC 479, but it showed monomorphic bands for C. parreyssi, C. gaillardoti together with C. canopicus (Figure 2a).

However, Primer UBC 478 (Figure 4a) showed DNA alteration concerning C. parreyssi, C. gaillardoti and C. canopicus. This DNA alteration might have resulted from mutation or rearrangements at or between oligonucleotide primer binding sites in a genome. Primer UBC 487 (Figure 6a) revealed monomorphic bands for all five studied Coelatura species.

Genetic diversity was also measured as the percentage of polymorphic bands for each primer (Tables 2 and 3 ). $9.26 \%$ of the bands were polymorphic among the five studied primers. Except primer UBC 487 which revealed no polymorphism, the other primers produced 1 to 6 polymorphic bands. Some RAPD fragments were found to be unique; 1 in C. parreyssi and C. gaillardoti and 3 in C. canopicus (Table 3).

Considering the similarity index (D) of the Coelatura species (Tables 5-9), utilizing RAPD-PCR markers, species were considered
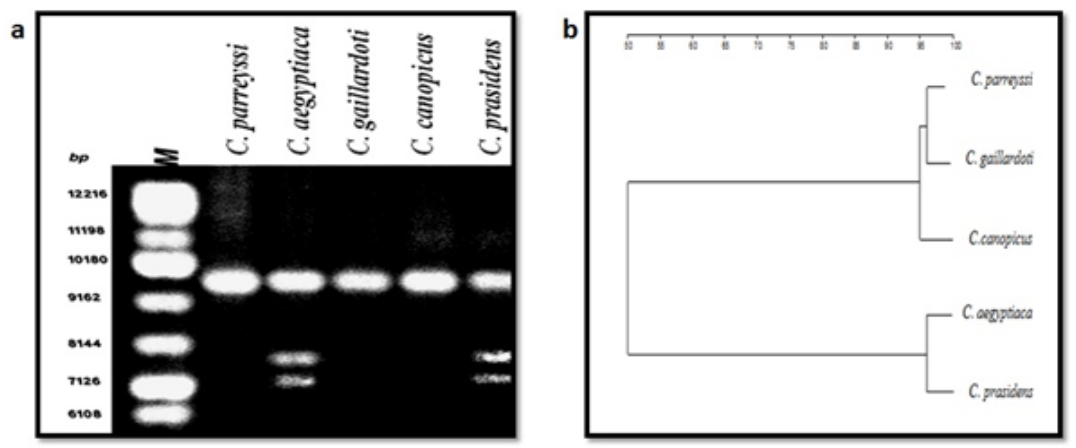

Figure 2: (a) RAPD-PCR profiles of the five Coelatura species under investigation using primer (UBC 476), and M: 1kb DNA marker shows one monomorphic band for all studied species and revealed 2, other monomorphic band for $C$. aegyptica and C. prasidens.

(b) Dendrogram of primer UBC 476 demonstrating the relationships of the five Coelatura species under investigation, based on compiled data set shows that C. parreyssi, C. gaillardoti identical species and C. canopicus are closed one also, C. aegyptiaca and C. prasidens similar species.
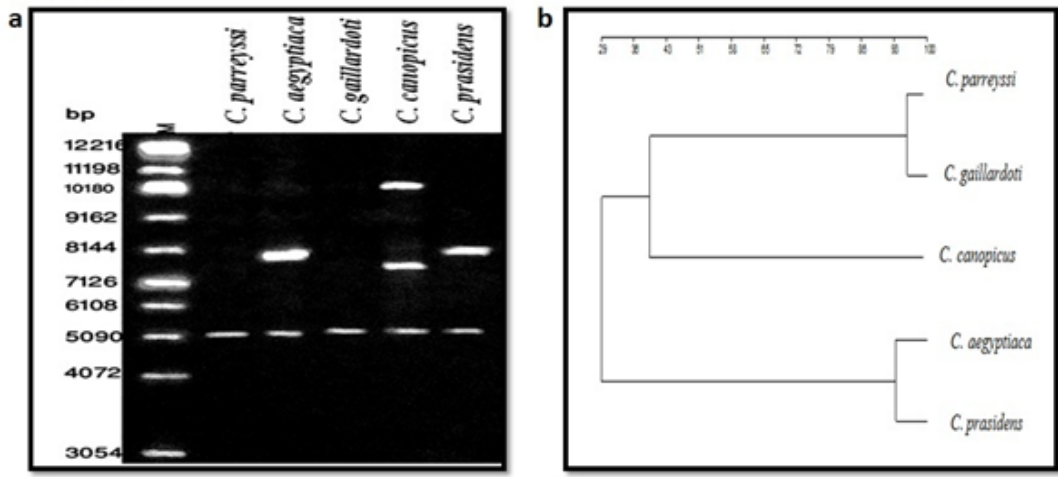

Figure 3: RAPD-PCR analysis of the five Coelatura species under investigation using primer (UBC 477)

(a) Gel electrophoresis showing amplification profile of samples. M: $1 \mathrm{~kb}$ DNA marker.

(b) Dendrogram demonstrating the similarity relationship between the five Coelatura species under investigation. 

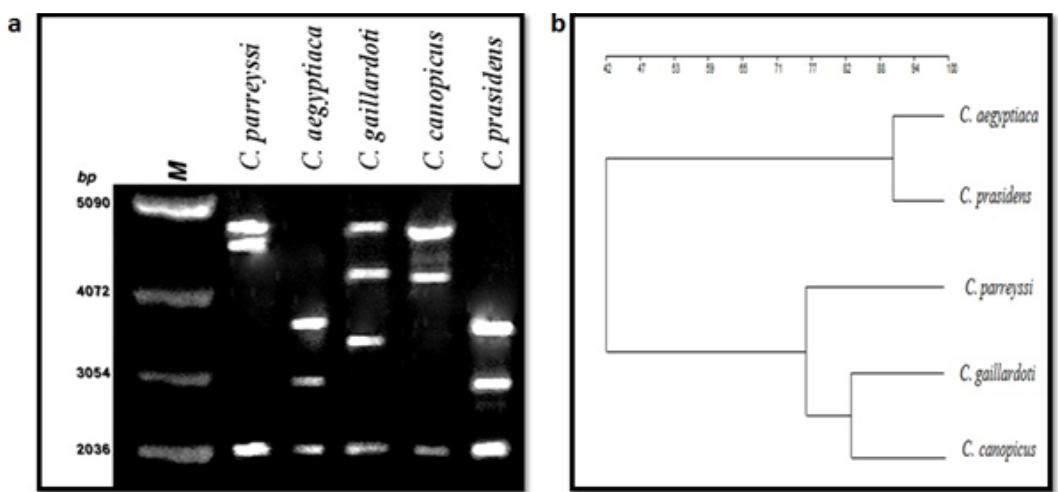

Figure 4: RAPD-PCR analysis of the five Coelatura species under investigation using primer (UBC 478)

(a) Gel electrophoresis showing amplification profile of samples. M: 1kb DNA marker.

(b) Dendrogram demonstrating the similarity relationship between the five Coelatura species under investigation
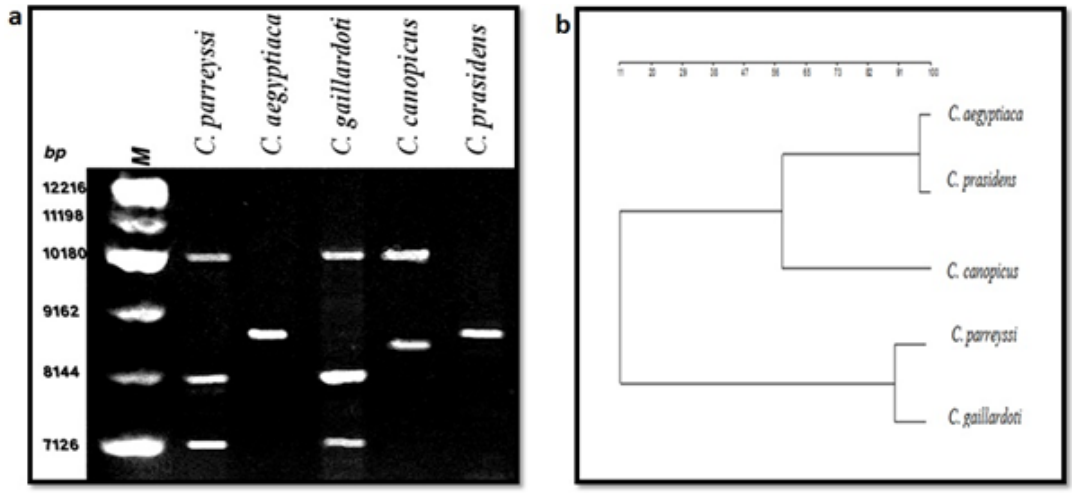

Figure 5: RAPD-PCR analysis of the five Coelatura species under investigation using primer (UBC 479)

(a) Gel electrophoresis showing amplification profile of samples. M: 1kb DNA marker.

(b) Dendrogram demonstrating the similarity relationship between the five Coelatura species under investigation.
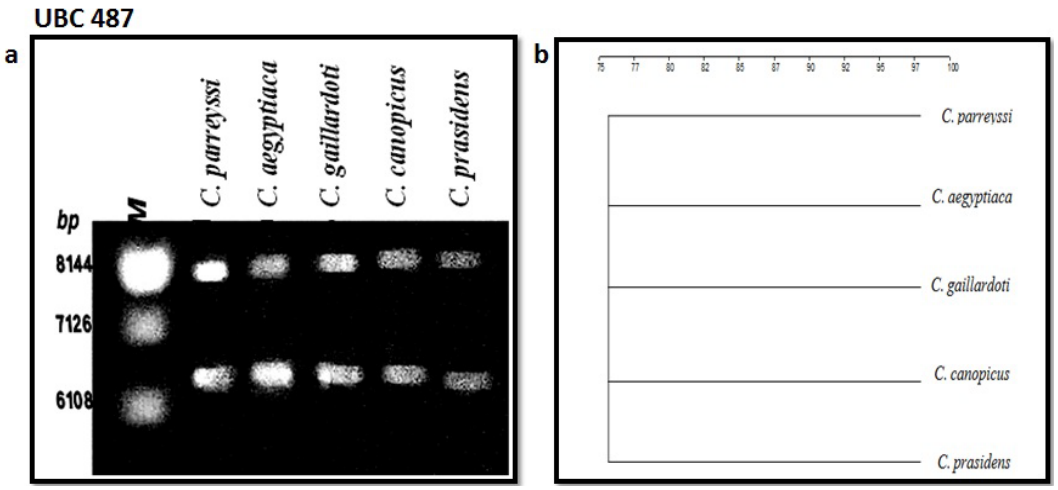

Figure 6: RAPD-PCR analysis of the five Coelatura species under investigation using primer (UBC 487)

(a) Gel electrophoresis amplification profile of samples M: $1 \mathrm{~kb}$ DNA marker.

(b) Dendrogram demonstrating the similarity relationship between the five Coelatura species under investigation

similar when the (D) value between two species is equal or close to 1 . While, when (D) is distant from 1 , the two species were regarded as separate species.

The similarity index (D) between C. aegyptiaca and C. prasidens, using all studied primers, was close to $1(0.90-0.97)$, thus they were the closest species, and were considered one species, C. aegyptiaca. While, it was distant from 1 between these two species and the other studied species, except for primer UBC 487 which showed no polymorphism. Also, the (D) value, using the primers UBC 476 and UBC 478, was close to 1 between C. parreyssi, C. gaillardoti and C. canopicus. However, using 
Citation: El Assal FM, Sabet SF, Varjabedian KG, Fol MF (2014) Pollution of Freshwater Coelatura species (Mollusca: Bivalvia: Unionidae) with Heavy Metals and its impact on the Ecosystem of the River Nile in Egypt. Int J Waste Resources 4: 163. doi: 10.4172/2252-5211.1000163

Page 5 of 11

\begin{tabular}{|c|c|c|c|c|c|}
\hline Primers/Species & C. parreyssi & C. aegyptiaca & C. gaillardoti & C. canopicus & C. prasidens \\
\hline \multicolumn{6}{|c|}{ UBC 476 (Figure 1a) } \\
\hline 1 & Band 1 at $~ 9671.16$ bp & Band 1 at $\sim 9677.96 \mathrm{bp}$ & Band 1 at $\sim 9732.50 \mathrm{bp}$ & Band 1 at $\sim 9739.76 \mathrm{pb}$ & Band 1 at $\sim 9759.88 \mathrm{bp}$ \\
\hline 2 & & Band 2 at $~ 7766.91 \mathrm{bp}$ & & & Band 2 at $\sim 7830.31 \mathrm{bp}$ \\
\hline 3 & & Band 3 at $\sim 7261.65 \mathrm{bp}$ & & & Band 3 at $\sim 7302.69 \mathrm{bp}$ \\
\hline \multicolumn{6}{|c|}{ UBC 477 (Figure 2a) } \\
\hline 1 & Band 1 at $\sim 5157.41 \mathrm{bp}$ & Band 1 at $\sim 8004.24 \mathrm{bp}$ & Band 1 at $\sim 5265.15 \mathrm{bp}$ & Band 1 at $\sim 10284.48 \mathrm{pb}$ & Band 1 at $\sim 8133.93 \mathrm{bp}$ \\
\hline 2 & & Band 2 at $\sim 5167.11 \mathrm{bp}$ & & Band 2 at $\sim 7655.77 \mathrm{bp}$ & Band 2 at $\sim 5265.15 \mathrm{bp}$ \\
\hline 3 & & & & Band 3 at $\sim 5265.15$ bp & \\
\hline \multicolumn{6}{|c|}{ UBC 478 (Figure 3a) } \\
\hline 1 & Band 1 at $\sim 4939.03 \mathrm{bp}$ & Band 1 at $\sim 3788.28 \mathrm{bp}$ & Band 1 at-4952.17 bp & Band 1 at $\sim 4890.24 \mathrm{bp}$ & Band 1 at $\sim 3716.02 \mathrm{bp}$ \\
\hline 2 & Band 2 at $\sim 4737.70 \mathrm{bp}$ & Band 2 at $\sim 3094.70 \mathrm{bp}$ & Band 2 at $\sim 4398.09 \mathrm{bp}$ & Band 2 at $\sim 4359.32 \mathrm{bp}$ & Band 2 at $\sim 3061.36 \mathrm{bp}$ \\
\hline 3 & Band 3 at $\sim 2154.60 \mathrm{bp}$ & Band 3 at $\sim 2158.54$ bp & Band 3 at $\sim 3554.15 \mathrm{bp}$ & Band 3 at $\sim 2131.12 b p$ & Band 3 at $\sim 2158.54 \mathrm{bp}$ \\
\hline 4 & & & Band 3 at $\sim 2158.54$ bp & & \\
\hline \multicolumn{6}{|c|}{ UBC 479 (Figure 4a) } \\
\hline 1 & Band 1 at $\sim 10195.41 \mathrm{bp}$ & Band 1 at $\sim 8834.00 \mathrm{bp}$ & Band 1 at $\sim 10272.82 \mathrm{bp}$ & Band 1 at $\sim 10319.55 \mathrm{bp}$ & Band 1 at $\sim 8825.74 \mathrm{bp}$ \\
\hline 2 & Band 3 at $\sim 8112.54 \mathrm{bp}$ & & Band 2 at $\sim 8174.51 \mathrm{bp}$ & Band 2 at $\sim 8654.18 \mathrm{bp}$ & \\
\hline 3 & Band 4 at $\sim 7153.63 \mathrm{bp}$ & & Band 3 at $\sim 7188.33 \mathrm{bp}$ & & \\
\hline \multicolumn{6}{|c|}{ UBC 487 (Figure 5a) } \\
\hline 1 & Band 1 at $\sim 8093.80 \mathrm{bp}$ & Band 1 at $\sim 8093.80 \mathrm{bp}$ & Band 1 at $\sim 8193.97$ bp & Band 1 at $\sim 8106.52 \mathrm{bp}$ & Band 1 at $\sim 8156.88 \mathrm{bp}$ \\
\hline 2 & Band 2 at $\sim 6542.64$ bp & Band 2 at $\sim 6542.64 \mathrm{bp}$ & Band 2 at $\sim 6556.28 \mathrm{bp}$ & Band 2 at $\sim 6583.66 \mathrm{bp}$ & Band 2 at $\sim 6529.02 \mathrm{bp}$ \\
\hline
\end{tabular}

Table 1: Bands Pattern in C. parreyssi, C. aegyptiaca, C. gaillardoti, C. canopicus and C. prasidens using the five primers.

\begin{tabular}{|c|c|c|c|}
\hline Primer & Total number of bands & Monomorphic & Polymorphic \\
\hline UBC 476 & 3 & 1 & 2 \\
\hline UBC 477 & 4 & 1 & 3 \\
\hline UBC 478 & 7 & 1 & 66.7 \\
\hline UBC 479 & 5 & 0 & 5 \\
\hline UBC 487 & 2 & 2 & 100 \\
\hline
\end{tabular}

Table 2: Total number of bands (monomorphic, polymorphic and percentage of polymorphism) of each primer, in Coelatura species under investigation. *The repeated bands in all species are counted once.

\begin{tabular}{|c|c|c|c|c|c|c|}
\hline Bands & Total & C. prasidens & C. canopicus & C. gaillardoti & C. aegyptiaca & C. parreyssi \\
\hline Amplified & 54 & 11 & 11 & 11 & 11 & 10 \\
\hline Monomorphic & 49 & 11 & 8 & 10 & 11 & 9 \\
\hline Polymorphic & 5 & 0 & 3 & 1 & 0 & 1 \\
\hline Unique & 5 & 0 & 3 & 1 & 0 & 1 \\
\hline$\%$ of polymorphism & 9.26 & $0 \%$ & $27.3 \%$ & $9.1 \%$ & $0 \%$ & $10 \%$ \\
\hline
\end{tabular}

Table 3: Total number of bands for all studied primers (monomorphic, polymorphic, unique) and percentage of polymorphism, revealed by RAPD markers among the five studied Coelatura species.

\begin{tabular}{|c|c|c|c|}
\hline Species & C. parreyssi & C. aegyptiaca & C. gaillardoti \\
\hline C. $a$ cogyptiaca & 0.53 & & \\
\hline C. gaillardoti & 0.96 & 0.51 & \\
\hline C. canopicus & 0.94 & 0.52 & 0.96 \\
\hline C. prasidens & 0.49 & 0.96 & 0.49 \\
\hline
\end{tabular}

Table 4: Similarity index (D) of the Egyptian Coelatura specie susing UBC 476 primer.

\begin{tabular}{|c|c|c|c|}
\hline Species & C. parreyssi & C. aegyptiaca & C. gaillardoti \\
\hline C. aegyptiaca & 0.29 & & \\
\hline C. gaillardoti & 0.96 & 0.28 & \\
\hline C. canopicus & 0.39 & 0.30 & 0.40 \\
\hline C. prasidens & 0.39 & 0.94 & 0.38 \\
\hline
\end{tabular}

Table 5: Similarity index (D) of the Egyptian Coelatura specie susing UBC 477 primer.

the primers UBC 477 and UBC 479, (D) was distant from 1. C. parreyssi and C. gaillardoti were the most closely associated species and may be considered one species, C. parreyssi. While, C. canopicus was somewhat distant and may be regarded as distinct species or subspecies.

The dendrogram analyses, using primers UBC 476, UBC 477 and UBC 479 (Figures $2 \mathrm{~b}, 3 \mathrm{~b}$ and $5 \mathrm{~b}$ ) confirmed the results obtained with the RAPD profiles and those of the (D) value. C. aegyptiaca and C. prasidens were the closest species, as well as are C. parreyssi and $C$. gaillardoti. While, C. canopicus was a separate species. The dendogram using primer UBC 478 showed the same result for C. aegyptiaca and C. 
Citation: El Assal FM, Sabet SF, Varjabedian KG, Fol MF (2014) Pollution of Freshwater Coelatura species (Mollusca: Bivalvia: Unionidae) with Heavy Metals and its impact on the Ecosystem of the River Nile in Egypt. Int J Waste Resources 4: 163. doi: 10.4172/2252-5211.1000163

Page 6 of 11

\begin{tabular}{|l|c|c|c|c|}
\hline \multicolumn{1}{|c|}{ Species } & C. parreyssi & C. aegyptiaca & C. gaillardoti & C. canopicus \\
\hline C. aegyptiaca & 0.55 & & & \\
\hline C. gaillardoti & 0.78 & 0.43 & & \\
\hline C. canopicus & 0.73 & 0.35 & 0.83 & \\
\hline C. prasidens & 0.47 & 0.91 & 0.39 & 0.30 \\
\hline
\end{tabular}

Table 6: Similarity index (D) of the Egyptian Coelatura specie susing UBC 478 primer.

\begin{tabular}{|l|c|c|c|c|}
\hline Species ar & C. parreyssi & C. aegyptiaca & C. gaillardoti & C. canopicus \\
\hline C. aegyptiaca & 0.02 & & & \\
\hline C. gaillardoti & 0.90 & 0.00 & & \\
\hline C. canopicus & 0.35 & 0.58 & 0.30 & \\
\hline C. prasidens & 0.01 & 0.97 & 0.008 & 0.58 \\
\hline
\end{tabular}

Table 7: Similarity index (D) of the Egyptian Coelatura specie susing UBC 479 primer.

\begin{tabular}{|l|c|c|c|c|}
\hline Species & C. parreyssi & C. aegyptiaca & C. gaillardoti & C. canopicus \\
\hline C. aegyptiaca & 0.91 & & & \\
\hline C. gaillardoti & 0.91 & 0.92 & & \\
\hline C. canopicus & 0.84 & 0.85 & 0.92 & \\
\hline C. prasidens & 0.74 & 0.90 & 0.77 & 0.85 \\
\hline
\end{tabular}

Table 8: Similarity index (D) of the Egyptian Coelatura specie susing UBC 487 primer.

$\wedge$ All studied species show high similarity index (D), ranging from 0.74 to 0.92

\begin{tabular}{|l|c|c|c|c|}
\hline Species & C. parreyssi & C. aegyptiaca & C. gaillardoti & C. canopicus \\
\hline C. aegyptiaca & 0.91 & & & \\
\hline C. gaillardoti & 0.91 & 0.92 & & \\
\hline C. canopicus & 0.84 & 0.85 & 0.92 & \\
\hline C. prasidens & 0.74 & 0.90 & 0.77 & 0.85 \\
\hline
\end{tabular}

Table 9: Similarity coefficient matrix of all primers calculated by NTSYS of the Egyptian Coelatura species.

prasidens, while some difference was revealed concerning C. parreyssi, C. gaillardoti and C. canopicus. The two latter species were the most related species and C. parreyssi was somewhat distant (Figure $4 \mathrm{~b}$ ).

According to the Similarity coefficient matrix of all primers (Table 9), the highest (D) value (0.55 and 0.67) was between C. gaillardoti and C. parreyssi and between C. prasidens and C. aegyptiaca. While, the lowest D-value (0.12) was recorded between $C$. gaillardoti and $C$. aegyptiaca, C. canopicus and C. aegyptiaca and between C. prasidens and C. parreyssi. This confirms that C. aegyptiaca and C. prasidens are similar and C. gaillardoti and C. parreyssi are also similar, while $C$. canopicus is different.

\section{Heavy metal analysis}

Nile water and sediment analysis: The mean values of the concentrations of the trace elements measured in the water and sediment of the studied areas (El-Kanater and Tura regions), are given in Table 10.

There was no significant difference $(\mathrm{P}>0.05)$ recorded in $\mathrm{Cu}$ and $\mathrm{Fe}$ measured in the water or sediment between both sites, while, significant difference $(\mathrm{P}<0.0001)$ in the concentration of $\mathrm{Pb}$ in the sediment and water between the two localities, was recorded. Also, Co concentration in the water showed significant difference $(\mathrm{P}<0.0001)$ between both sites. $\mathrm{Ni}$ and $\mathrm{Mn}$ revealed, too, significant difference $(\mathrm{P}<0.0001)$ in the sediment between the two regions.

Trace elements recorded in the Nile water of both regions were in the permissible levels for $\mathrm{Cu}, \mathrm{Mn}$ and $\mathrm{Fe}$, while the levels of $\mathrm{Co}, \mathrm{Pb}$ and Ni exceeded these levels (Table 10).
The concentrations of the different studied heavy metals in water of the two locations were in the following decreasing order:

Tura region: $\mathrm{Fe}>\mathrm{Co}>\mathrm{Ni}>\mathrm{Mn}>\mathrm{Pb}>\mathrm{Cu}$

El-Kanater region: $\mathrm{Fe}>\mathrm{Co}>\mathrm{Ni}>\mathrm{Mn}>\mathrm{Pb}>\mathrm{Cu}$

Metal concentrations in the sediment of the two locations were in the following sequence:

Tura region : $\mathrm{Fe}>\mathrm{Mn}>\mathrm{Ni}>\mathrm{Pb}>\mathrm{Co}>\mathrm{Cu}$

El-Kanater region: $\mathrm{Fe}>\mathrm{Mn}>\mathrm{Co}>\mathrm{Ni}>\mathrm{Cu}>\mathrm{Pb}$

\section{Tissue analysis}

There was a great variation in the amount of the trace elements accumulated in the different soft parts of the studied mussels (Tables 11-14).

In general, significant difference was recorded in the concentration of the studied heavy metals in the different soft parts, between the studied Coelatura species $(\mathrm{P}<0.05, \mathrm{P}<0.0001)$, at the two localities under investigation, except in some instance.

Heavy metals analyzed in all tissues of the three studied Coelatura species exceeded the permissible levels according to WHO [28] and FAO/WHO [29]. The calculated transfer factor (TF) in the different tissues from water and sediments at the two localities is shown in Tables 15-17. Results show that the TF of the sediments was greater than that of water.

\section{Discussion}

Human exploitation of world mineral resources and advances in industrialization has resulted in high levels of heavy metals in the environment [30-32]. The aquatic bodies near the industrial and urban areas are more able to accumulate such metals, causing hazardous impact on the freshwater fauna. The impact of metals on different bivalve populations revealed that those inhabiting environments contaminated by heavy metals exhibited a higher allelic diversity [33]. DNA damage and genetic diversity in aquatic animal populations induced by chemical contaminants have been successfully detected using RAPD method [34-37].

RAPD-PCR analysis proved to be helpful in estimating genetic variations among species $[11,38]$. Analyses of the RAPD-PCR showed natural differences or polymorphism among the Coelatura species under investigation, and distinguished them to only three species namely, C. aegyptiaca, C. parreyssi and C. canopicus which were also confirmed by dendograms and (D) values. In fact, thorough revision of genus Coelatura was needed by applying molecular techniques to reveal the current concept that it represents a lumped species complex, as claimed by Ortmann [39], Graf [40] and Graf and Cummings [12].

The present study shows that C. aegyptiaca and C. prasidens are closely related and could be considered as one species, C. aegyptiaca, which is the type species of the genus Coelatura. Also, C. parreyssi and C. gaillardoti are closely related and are considered as the same species, C. parreyssi, which has advantage over C. gaillardoti because of nomenclature priority [41]. On the other hand, C. canopicus is somewhat distant from the other studied species and may be considered a separate species or a subspecies. Finally, the similarity coefficient matrix and the UPGMA dendogram of all primers confirmed that the five Coelatura species under investigation should be classified into three species only namely, C. aegyptiaca, C. parreyssi and C. canopicus (Figure 7). Thus, assessing the genetic diversity of populations could 
Citation: El Assal FM, Sabet SF, Varjabedian KG, Fol MF (2014) Pollution of Freshwater Coelatura species (Mollusca: Bivalvia: Unionidae) with Heavy Metals and its impact on the Ecosystem of the River Nile in Egypt. Int J Waste Resources 4: 163. doi: 10.4172/2252-5211.1000163

Page 7 of 11

\begin{tabular}{|c|c|c|c|c|c|c|}
\hline $\begin{array}{c}\text { Metals } \\
\text { Parameters }\end{array}$ & $\mathbf{F e}$ & $\mathbf{M n}$ & $\mathbf{N i}$ & $\mathbf{C o}$ & $\mathbf{C u}$ & $\mathbf{P b}$ \\
\hline Sediment at Tura & $303.26 \pm 60.7$ & $198.7 \pm 12.2$ & $5.32 \pm 0.43$ & $3.9 \pm 0.72$ & $3.34 \pm 0.2$ & $5.24 \pm 0.53$ \\
\hline Sediment at El-Kanater & $245.08 \pm 20.87$ & $234.67 \pm 10.6$ & $3.64 \pm 0.48$ & $3.7 \pm 0.47$ & $3.2 \pm 0.19$ & $2.7 \pm 0.4$ \\
\hline P value & $\mathrm{P}>0.05$ & ${ }^{*} \mathrm{P}<0.0001$ & ${ }^{*} \mathrm{P}<0.0001$ & $\mathrm{P}>0.05$ & $\mathrm{P}>0.05$ & ${ }^{*} \mathrm{P}<0.0001$ \\
\hline Water at Tura & $0.26 \pm 0.03$ & $0.052 \pm 0.01$ & $0.06 \pm 0.012$ & $0.22 \pm 0.13$ & $0.022 \pm 0.008$ & $0.05 \pm 0.01$ \\
\hline Water at El-Kanater & $0.14 \pm 0.076$ & $0.04 \pm 0.004$ & $0.05 \pm 0.005$ & $0.09 \pm 0.007$ & $0.03 \pm 0.01$ & $0.032 \pm 0.008$ \\
\hline P value* & $\mathrm{P}>0.05$ & $\mathrm{P}>0.05$ & $\mathrm{P}>0.05$ & ${ }^{*} \mathrm{P}<0.0001$ & $\mathrm{P}>0.05$ & ${ }^{*} \mathrm{P}<0.0001$ \\
\hline Permissible levels of water & 1 & 0.4 & 0.02 & $0.001-0.002$ & 2 & 0.01 \\
\hline
\end{tabular}

Table10: Concentration of heavy metals (in ppm) in water and sediment of the River Nile at El-Kanater and Tura regions, and the permissible levels in water according to the WHO $(2008,1996)$

${ }^{*}$ Significant at $\mathrm{P}<0.0001$ and insignificant at $\mathrm{P}<0.05$

\begin{tabular}{|c|c|c|c|c|c|c|c|c|}
\hline \multirow{2}{*}{ Heavy metals } & \multicolumn{3}{|c|}{ Tura region } & \multirow{2}{*}{ P- value } & \multicolumn{3}{|c|}{ El-Kanater region } \\
\cline { 2 - 7 } & C. aegyptiaca & C.canopicus & C. parreyssi & C. aegyptiaca & C.canopicus & C. parreyssi & P- value & *Permissible \\
levels in mg/kg
\end{tabular}

Table 11: Mean concentrations of the heavy metals in the foot of $C$. aegyptiaca, C. parreyssi and C. canopicusin $\mathrm{g} / \mathrm{kg}$ at Tura and El-Kanater regions \pm standard deviation. ${ }^{*}$ Permissible levels of heavy metals according to FAO/WHO, (1999).

${ }^{* *}$ Permissible levels of $\mathrm{Ni}$ according to WHO (1989).

*** Significant at $P<0.05, P<0.0001$ and insignificant at $P>0.05$

\begin{tabular}{|c|c|c|c|c|c|c|c|c|c|}
\hline \multirow{2}{*}{ Heavy metals } & \multicolumn{3}{|c|}{ Tura region } & \multirow{2}{*}{$P$ - value } & \multicolumn{3}{|c|}{ EI-Kanater region } & \multirow{2}{*}{ P-value } & \multirow{2}{*}{$\begin{array}{l}\text { *Permissible } \\
\text { levels in } \mathrm{mg} / \mathrm{kg}\end{array}$} \\
\hline & C. aegyptiaca & C.canopicus & C. parreyssi & & C. aegyptiaca & C.canopicus & C. parreyssi & & \\
\hline Lead & $\begin{array}{c}0.25 \\
(0.00025 \mathrm{~g})\end{array}$ & ${ }^{* * *} \mathrm{P}<0.0001$ & $9.4 \pm 1.1$ & $4.5 \pm 1$ & $2.59 \pm 0.7$ & ${ }^{* * *} P<0.0001$ & $7.63 \pm 2.13$ & $3.3 \pm 0.76$ & $3.8 \pm 0.74$ \\
\hline Copper & $3(0.003 \mathrm{~g})$ & $P>0.05$ & $3.99 \pm 0.4$ & $3.94 \pm 0.3$ & $3.9 \pm 0.34$ & ${ }^{* * *} \mathrm{P}<0.0001$ & $7.15 \pm 0.89$ & $7.22 \pm 1$ & $10.4 \pm 1.24$ \\
\hline Cobalt & - & ${ }^{* * *} \mathrm{P}<0.0001$ & $5.1 \pm 0.7$ & $3.8 \pm 0.83$ & $2.57 \pm 0.55$ & ${ }^{* * *} \mathrm{P}<0.0001$ & $14.56 \pm 2.4$ & $11.69 \pm 1.52$ & $7 \pm 1$ \\
\hline Nickel $^{* *}$ & $\begin{array}{c}0.5-1.0 \\
(0.0005-0.001 \mathrm{~g})\end{array}$ & ${ }^{* * *} P<0.0001$ & $2.5 \pm 0.6$ & $4.3 \pm 0.4$ & $6.13 \pm 1.3$ & ${ }^{* * *} \mathrm{P}<0.05$ & $7.9 \pm 0.69$ & $11 \pm 2.5$ & $11.57 \pm 3.2$ \\
\hline Manganese & $\begin{array}{c}2-9 \\
(0.002-0.009 \mathrm{~g})\end{array}$ & ${ }^{* * *} \mathrm{P}<0.0001$ & $178 \pm 58.4$ & $376.7 \pm 43$ & $649 \pm 82.9$ & ${ }^{* * *} P<0.0001$ & $568.2 \pm 104.7$ & $475.3 \pm 70.7$ & $392.94 \pm 19.8$ \\
\hline Iron & $\begin{array}{c}43 \\
(0.043 \mathrm{~g})\end{array}$ & ${ }^{* * *} P<0.0001$ & $356.5 \pm 36.2$ & $511.86 \pm 40$ & $638.4 \pm 54.6$ & ${ }^{* * *} P<0.0001$ & $473.8 \pm 47.26$ & $481.6 \pm 74.27$ & $238.8 \pm 31.7$ \\
\hline
\end{tabular}

Table 12: Mean concentrations of the heavy metals in the mantle of C. aegyptiaca, C. parreyssi and C. canopicusin $\mathrm{g} / \mathrm{kg}$ at Tura and El-Kanater regions \pm standard deviation.

${ }^{*}$ Permissible levels of heavy metals according to FAO/WHO, (1999).

${ }^{* *}$ Permissible levels of Ni according to WHO (1989).

*** Significant at $\mathrm{P}<0.05, \mathrm{P}<0.0001$ and insignificant at $\mathrm{P}>0.05$

\begin{tabular}{|c|c|c|c|c|c|c|c|c|c|}
\hline \multirow{2}{*}{$\begin{array}{l}\text { Heavy } \\
\text { metals }\end{array}$} & \multicolumn{3}{|c|}{ Tura region } & \multirow{2}{*}{$P$ - value } & \multicolumn{3}{|c|}{ EI-Kanater region } & \multirow{2}{*}{$P$ - value } & \multirow{2}{*}{$\begin{array}{c}{ }^{*} \text { Permissible levels } \\
\text { in } \mathrm{mg} / \mathrm{kg}\end{array}$} \\
\hline & C. aegyptiaca & C.canopicus & C. parreyssi & & C. aegyptiaca & C.canopicus & C. parreyssi & & \\
\hline Lead & $\begin{array}{c}0.25 \\
(0.00025 \mathrm{~g})\end{array}$ & ${ }^{* * *} P<0.0001$ & $7.27 \pm 1.1$ & $5.33 \pm 1.1$ & $4.85 \pm 0.56$ & $P>0.05$ & $2.54 \pm 0.58$ & $2.94 \pm 0.62$ & $2.35 \pm 0.78$ \\
\hline Copper & $3(0.003 \mathrm{~g})$ & $P>0.05$ & $5.9 \pm 0.44$ & $5.32 \pm 0.7$ & $5.6 \pm 1.2$ & ${ }^{* * *} \mathrm{P}<0.05$ & $10.98 \pm 1$ & $13.45 \pm 1.96$ & $11.9 \pm 0.98$ \\
\hline Cobalt & - & ***$P<0.0001$ & $9.3 \pm 1.1$ & $7.3 \pm 0.76$ & $8.5 \pm 1$ & ${ }^{* * *} \mathrm{P}<0.0001$ & $3.77 \pm 1.2$ & $5.45 \pm 0.79$ & $9.99 \pm 1.5$ \\
\hline Nickel $^{* *}$ & $\begin{array}{c}0.5-1.0 \\
(0.0005-0.001 \mathrm{~g})\end{array}$ & $* * * P<0.0001$ & $6.67 \pm 0.44$ & $5.94 \pm 1.2$ & $3.6 \pm 0.7$ & ${ }^{* * *} \mathrm{P}<0.05$ & $11 \pm 0.47$ & $9.7 \pm 1.2$ & $11.2 \pm 0.86$ \\
\hline Manganese & $\begin{array}{c}2-9 \\
(0.002-0.009 \mathrm{~g})\end{array}$ & $* * * P<0.0001$ & $447 \pm 26.54$ & $120.75 \pm 41$ & $136.56 \pm 5.25$ & ${ }^{* * *} \mathrm{P}<0.0001$ & $142.78 \pm 25.75$ & $498.1 \pm 72.8$ & $282.02 \pm 17.63$ \\
\hline Iron & $\begin{array}{c}43 \\
(0.043 \mathrm{~g}) \\
\end{array}$ & ${ }^{* * *} P<0.0001$ & $261.8 \pm 25.49$ & $224.81 \pm 30.66$ & $155.98 \pm 12.32$ & $P>0.05$ & $144.49 \pm 24.78$ & $105.83 \pm 81.9$ & $152.47 \pm 23.375$ \\
\hline
\end{tabular}

Table 13: Mean concentrations of the heavy metals in the gills of $C$. aegyptiaca, C. parreyssi and C. canopicusin $\mathrm{g} / \mathrm{kg}$ at Tura and El-Kanater regions \pm standard deviation.

${ }^{*}$ Permissible levels of heavy metals according to FAO/WHO, (1999).

** Permissible levels of $\mathrm{Ni}$ according to WHO (1989).

*** Significant at $\mathrm{P}<0.05, \mathrm{P}<0.0001$ and insignificant at $\mathrm{P}>0.05$ 
Citation: El Assal FM, Sabet SF, Varjabedian KG, Fol MF (2014) Pollution of Freshwater Coelatura species (Mollusca: Bivalvia: Unionidae) with Heavy Metals and its impact on the Ecosystem of the River Nile in Egypt. Int J Waste Resources 4: 163. doi: 10.4172/2252-5211.1000163

Page 8 of 11

\begin{tabular}{|c|c|c|c|c|c|c|c|c|c|}
\hline \multirow{2}{*}{ Heavy metals } & \multicolumn{3}{|c|}{ Tura region } & \multirow{2}{*}{ P-value } & \multicolumn{3}{|c|}{ El-Kanater region } & \multirow{2}{*}{$P$-value } & \multirow{2}{*}{$\begin{array}{c}\text { * Permissible levels } \\
\text { in } \mathrm{mg} / \mathrm{kg}\end{array}$} \\
\hline & C. aegyptiaca & C.canopicus & C. parreyssi & & C. aegyptiaca & C.canopicus & C. parreyssi & & \\
\hline Lead & $\begin{array}{c}0.25 \\
(0.00025 \mathrm{~g})\end{array}$ & ${ }^{* \star *} P<0.0001$ & $3.3 \pm 0.6$ & $3.44 \pm 0.2$ & $5.1 \pm 0.54$ & ${ }^{* * * P} P<0.05$ & $8.45 \pm 0.98$ & $7.44 \pm 1.1$ & $6.6 \pm 1.3$ \\
\hline Copper & $3(0.003 \mathrm{~g})$ & ${ }^{* * *} P<0.0001$ & $8.4 \pm 0.7$ & $6.56 \pm 0.44$ & $4.75 \pm 0.24$ & *** $P<0.0001$ & $4.9 \pm 0.47$ & $6.4 \pm 0.89$ & $7.16 \pm 1$ \\
\hline Cobalt & - & ${ }^{* * *} P<0.05$ & $1.63 \pm 0.3$ & $1.26 \pm 0.3$ & $1.1 \pm 0.07$ & ${ }^{* * *} P<0.05$ & $1.1 \pm 0.4$ & $2.3 \pm 0.54$ & $2.55 \pm 1.17$ \\
\hline Nickel** & $\begin{array}{c}0.5-1.0 \\
(0.0005-0.001 \mathrm{~g})\end{array}$ & ${ }^{* \star *} P<0.0001$ & $7.3 \pm 1.5$ & $5.8 \pm 0.99$ & $3.93 \pm 0.6$ & ***P<0.0001 & $2.7 \pm 1.3$ & $6.1 \pm 0.5$ & $7.4 \pm 1$ \\
\hline Manganese & $\begin{array}{c}2-9 \\
(0.002-0.009 \mathrm{~g})\end{array}$ & ${ }^{* * *} P<0.0001$ & $70 \pm 14.82$ & $115.4 \pm 15.35$ & $153.5 \pm 33$ & ***P<0.0001 & $628.9 \pm 53.7$ & $358 \pm 120.8$ & $333.3 \pm 33$ \\
\hline Iron & $\begin{array}{c}43 \\
(0.043 \mathrm{~g})\end{array}$ & ${ }^{* \star *} P<0.0001$ & $758.7 \pm 22.4$ & $669.45 \pm 27.35$ & $453.2 \pm 17.4$ & ***P<0.0001 & $235.2 \pm 93.9$ & $911.69 \pm 85$ & $152.88 \pm 13.17$ \\
\hline
\end{tabular}

Table 14: Mean concentrations of the heavy metals in the digestive tissues of $C$. aegyptiaca, C. parreyssi and C. canopicusin $\mathrm{g} / \mathrm{kg}$ at Tura and El-Kanater regions \pm standard deviation.

${ }^{*}$ Permissible levels of heavy metals according to FAO/WHO, (1999).

${ }^{* *}$ Permissible levels of Ni according to WHO (1989).

${ }^{* * *}$ Significant at $\mathrm{P}<0.05, \mathrm{P}<0.0001$ and insignificant at $\mathrm{P}>0.05$

\begin{tabular}{|c|c|c|c|c|c|c|c|c|c|c|c|c|}
\hline Site & \multicolumn{9}{|c|}{ Tura } & \multicolumn{5}{c|}{ El kanater } \\
\hline Heavy metals & $\mathrm{Pb}$ & $\mathrm{Cu}$ & $\mathrm{Co}$ & $\mathrm{Ni}$ & $\mathrm{Mn}$ & $\mathrm{Fe}$ & $\mathrm{Pb}$ & $\mathrm{Cu}$ & $\mathrm{Co}$ & $\mathrm{Ni}$ & $\mathrm{Mn}$ & $\mathrm{Fe}$ \\
\hline Water/Foot & 0.007 & 0.002 & 0.043 & 0.01 & 0.003 & 0.0003 & 0.008 & 0.003 & 0.01 & 0.01 & 0.0002 & 0.0005 \\
\hline Water/Mantle & 0.013 & 0.002 & 0.037 & 0.01 & 0.0001 & 0.0008 & 0.012 & 0.008 & 0.004 & 0.01 & 0.0001 & 0.0002 \\
\hline Water/Gill & 0.02 & 0.002 & 0.026 & 0.01 & 0.0002 & 0.0013 & 0.006 & 0.005 & 0.001 & 0.01 & 0.0003 & 0.0009 \\
\hline Water/Digestive tissue & 0.008 & 0.003 & 0.1 & 0.01 & 0.0002 & 0.0013 & 0.006 & 0.006 & 0.008 & 0.01 & 0.0003 & 0.0003 \\
\hline Sediment/Foot & 0.72 & 0.3 & 0.7 & 0.76 & 1.2 & 0.46 & 0.7 & 0.3 & 4.4 & 1.0 & 1.0 & 0.9 \\
\hline Sediment/Mantle & 1.4 & 0.3 & 0.6 & 0.44 & 0.5 & 1.3 & 1.0 & 0.8 & 1.4 & 0.6 & 0.36 & 0.4 \\
\hline Sediment/Gill & 2.2 & 0.3 & 0.4 & 0.46 & 0.7 & 2.0 & 0.6 & 0.6 & 0.4 & 1.0 & 1.7 & 1.6 \\
\hline Sediment/Digestive tissue & 0.8 & 0.5 & 1.5 & 0.7 & 0.6 & 2 & 0.5 & 0.7 & 3.4 & 0.93 & 1.53 & 0.54 \\
\hline
\end{tabular}

Table 15: Mean transfer factor (TF) of the different heavy metals in the different soft parts of $C$. aegyptiaca (g/kg dry weight) and in Nile water samples (mg/l) from Tura and El-Kanater regions.

\begin{tabular}{|c|c|c|c|c|c|c|c|c|c|c|c|c|}
\hline \multirow{2}{*}{$\begin{array}{c}\text { Site } \\
\text { Heavy metals }\end{array}$} & \multicolumn{6}{|c|}{ Tura } & \multicolumn{6}{|c|}{ El kanater } \\
\hline & $\mathrm{Pb}$ & $\mathrm{Cu}$ & Co & $\mathrm{Ni}$ & $\mathrm{Mn}$ & $\mathrm{Fe}$ & $\mathrm{Pb}$ & $\mathrm{Cu}$ & Co & $\mathrm{Ni}$ & $\mathrm{Mn}$ & $\mathrm{Fe}$ \\
\hline Water/Foot & 0.004 & 0.002 & 0.05 & 0.1 & 0.0001 & 0.0004 & 0.002 & 0.005 & 0.002 & 0.01 & 0.0001 & 0.0003 \\
\hline Water/Mantle & 0.007 & 0.003 & 0.02 & 0.01 & 0.0001 & 0.0004 & 0.003 & 0.008 & 0.002 & 0.02 & 0.0002 & 0.0004 \\
\hline Water/Gill & 0.02 & 0.002 & 0.07 & 0.01 & 0.0004 & 0.0014 & 0.004 & 0.005 & 0.001 & 0.01 & 0.0001 & 0.0005 \\
\hline Water/Digestive tissue & 0.006 & 0.004 & 0.24 & 0.02 & 0.0001 & 0.0009 & 0.009 & 0.004 & 0.006 & 0.01 & 0.0006 & 0.0002 \\
\hline Sediment/Foot & 0.4 & 0.4 & 0.7 & 9.6 & 0.7 & 0.64 & 0.2 & 0.5 & 0.7 & 0.95 & 0.77 & 0.54 \\
\hline Sediment/Mantle & 0.7 & 0.5 & 0.3 & 0.65 & 0.35 & 0.64 & 0.7 & 0.8 & 0.7 & 1.46 & 1.32 & 0.7 \\
\hline Sediment/Gill & 2.1 & 0.3 & 1.0 & 0.5 & 1.4 & 1.3 & 0.4 & 0.5 & 0.4 & 0.55 & 0.53 & 0.94 \\
\hline Sediment/Digestive tissue & 0.6 & 0.7 & 3.5 & 1.97 & 0.32 & 1.3 & 0.8 & 0.4 & 2.3 & 0.5 & 3.36 & 0.32 \\
\hline
\end{tabular}

Table 16: Mean transfer factor (TF) of the different heavy metals in the different soft parts of $C$. parreyssi (g/kg dry weight) and in Nile water samples (mg/l) from Tura and El-Kanater regions.

\begin{tabular}{|c|c|c|c|c|c|c|c|c|c|c|c|c|}
\hline \multirow{2}{*}{$\begin{array}{c}\text { Site } \\
\text { Heavy metals }\end{array}$} & \multicolumn{6}{|c|}{ Tura } & \multicolumn{6}{|c|}{ El kanater } \\
\hline & $\mathrm{Pb}$ & $\mathrm{Cu}$ & Co & $\mathrm{Ni}$ & $\mathrm{Mn}$ & $\mathrm{Fe}$ & $\mathrm{Pb}$ & $\mathrm{Cu}$ & Co & $\mathrm{Ni}$ & $\mathrm{Mn}$ & $\mathrm{Fe}$ \\
\hline Water/Foot & 0.008 & 0.001 & 0.057 & 0.02 & 0.0001 & 0.0004 & 0.003 & 0.004 & 0.003 & 0.02 & 0.0002 & 0.0004 \\
\hline Water/Mantle & 0.015 & 0.003 & 0.022 & 0.01 & 0.0001 & 0.0004 & 0.007 & 0.008 & 0.002 & 0.01 & 0.0001 & 0.0003 \\
\hline Water/Gill & 0.017 & 0.001 & 0.05 & 0.01 & 0.0001 & 0.002 & 0.006 & 0.006 & 0.001 & 0.01 & 0.0003 & 0.0006 \\
\hline Water/Digestive tissue & 0.007 & 0.003 & 0.1 & 0.01 & 0.0001 & 0.0002 & 0.009 & 0.005 & 0.007 & 0.01 & 0.0003 & 0.0002 \\
\hline Sediment/Foot & 0.9 & 0.2 & 0.9 & 1.33 & 0.37 & 0.53 & 0.3 & 0.4 & 1.2 & 1.16 & 0.9 & 0.72 \\
\hline Sediment/Mantle & 1.6 & 0.5 & 0.3 & 0.5 & 0.42 & 0.63 & 0.6 & 0.8 & 1.0 & 0.85 & 0.62 & 0.48 \\
\hline Sediment/Gill & 1.8 & 0.2 & 0.7 & 0.54 & 0.4 & 0.33 & 0.5 & 0.6 & 0.5 & 0.6 & 1.94 & 1.1 \\
\hline Sediment/Digestive tissue & 0.7 & 0.5 & 1.7 & 0.87 & 0.56 & 0.33 & 0.8 & 0.5 & 2.9 & 0.63 & 2.0 & 0.37 \\
\hline
\end{tabular}

Table 17: Mean transfer factor (TF) of the different heavy metals in the different soft parts of $C$. canopicus (g/kg dry weight) and in Nile water samples (mg/l) from Tura and El-Kanater regions.

be a valuable addition to more traditional tools for determining the effects of environmental pollution on aquatic ecosystems as confirmed by Nevo et al. [42], Bickham and Smolen [43] and Nadig et al. [34].

Primer UBC 478 showed DNA alteration concerning C. parreyssi,
C. gaillardoti and C.canopicus. The gain/loss of RAPD bands may be related to DNA damage, mutation or structural rearrangements induced by genotoxic agents affecting the primer sites [37]. Mutation may be due to quantitative or qualitative changes or rearrangement of 

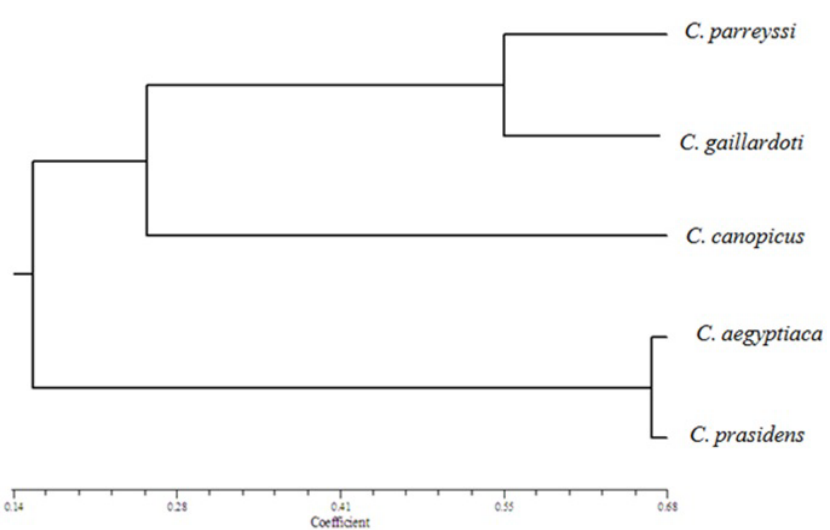

Figure 7: Dendrogram of cluster analyses of the five Coelatura species under investigation according to RAPD data obtained using Jaccard's coefficient and UPGMA method.

the genetic material, most probably due to metal $(\mathrm{Pb}, \mathrm{Mn}, \mathrm{Cu}, \mathrm{Fe}, \mathrm{Co}$ and $\mathrm{Ni}$ ) pollution of the environment, recorded in the two localities of the study. The concept that genetic patterns within populations may be altered by exposure to contaminants was reported by Bishop and Cook (1981) [8], Klerks and Weis [9], Abdul-Aziz [44] and Giantsis et al. [38]. Also, the latter authors, examining genetic differentiation and potential impact of heavy metals pollution, using RAPD markers, observed a loss in genetic variability of Mytilus galloprovincialis population. They concluded that metal pollution appears to have played an important role in shapping pattern of genetic diversity and differentiation among Greek M. galloprovincialis population. Yap et al. [45] found that heavy metal contamination was a main causal agent for the genetic differentiation of Pera viridis in Peninsula Malaysia. The evidence for pollutant to induce genotoxicity has been also determined by several authors $[33,38,46-50]$. Neeratanaphan et al. [51] postulated that understanding the effect of heavy metals on genetic variability is fundamental for preservation. They detected genomic DNA modification such as damage and structure variation in the freshwater snail Filopaludina martensi affected by lead and cadmium

Forni [52] and Reid et al. [53] reported $\mathrm{Cu}, \mathrm{Fe}, \mathrm{Cd}$ and $\mathrm{Ni}$ as mutagenic agents. These metals have the tendency to bind to phosphates and wide variety of organic molecules including base residues of DNA, which can lead to mutations by altering structures of DNA [54] or modifying the genetic diversity of populations. Also, exposure of mussels in the field to water polluted by different mixtures of genotoxic contaminants was reported by Izquierdo et al. [55] to induce DNA alterations, leading to genetic variation among species and populations. Thus, the conflict in the taxonomy of Coelatura species in the different studies is most probably due to the environmental pollution with heavy metals among other factors. Heavy metals analysed in all tissues of the studied Coelatura species exceeded the permissible levels according to WHO (1989) [28] and FAO/WHO [29].

The numbers of threatened aquatic species and species extinctions increase at an alarming rate [56]. Molluscs are one of the most threatened major taxonomic groups worldwide [57]. Within this group, the unionids are highly threatened throughout their distribution [58] and are declining globally due to alteration in habitat, decline and extinction of fish host populations, pollution and environmental changes, pointing toward impending extinction. They are the most imperiled group of species and many species became extinct in several parts of the world including Egypt, while others are threatened or endangered. The loss of benthic biomass may result in large scale alterations of freshwater ecosystem processes and functions [59].

Little information is available about the effect of frequent exposure to metals on mussels; it is possible that higher metal amounts than required could be a contributing factor to the extinction of some mussel species and genetic variation of some other species. In fact, the mussel fauna in Egypt is threatened due to heavy metal pollution of the River Nile water and sediment among other factors.

All species of genus Unio which were used to live in the River Nile are today extinct [10]. Only fossils were recorded by these authors from El Fayoum, Komombo, Idfu and Isna i.e from Upper Egypt. Although, some investigators $[60,61]$ have referred to living Unio specimens in the River Nile in Lower Egypt. But, this is uncertain and needs to be thoroughly revised and the occurrence of Unio species in Egypt is still doubtful.

In general, studies on heavy metals are important in two main aspects, the public health point of view and the aquatic environment conservation. Heavy metals are present in the aquatic environment where they can accumulate along the food chain. Moreover, small amounts of absorbed heavy metals are either stored in a metabolically available form for essential biochemical processes or detoxified into metabolically inert forms and held in the body either temporarily or permanently [62-64]. Thus, determination of chemical quality of aquatic organisms, particularly the content of heavy metals is extremely important.

\section{References}

1. Hochwald S, Bauer G (1988) Gutachten zur Bestandssituation und zumschutz der Bachmuschel Unio crassus (Phil.) Fischer und Teichwirt, 12: 366-371.

2. Ashraf W (2005) Accumulation of heavy metals in kidney and heart tissues of Epinephelus microdon fish from the Arabian Gulf. Environ Monit Assess 101 311-316.

3. Al-Weher SM (2008) Levels of heavy metals $\mathrm{Cd}, \mathrm{Cu}$ and $\mathrm{Zn}$ in three fish species collected from the Northern Jordan Valley, Jordan. Jordan Journal of Biological Sciences 1: 41-46

4. Bala M, Shehu RA, Lawal M (2008) Determination of the level of some heavy metals in water collected from two pollution- Prone irrigation areas around Kano Metropolis. Bayero Journal of Pure and Applied Sciences 1: 36-38.

5. Obasohan EE, Oronsaye JAO, Eguavoen OI (2008) A comparative Assessment of the heavy metal loads in the tissues of a common catfish (Clarias gariepinus) from Ikpoba and Ogba Rivers in Benin City, Nigeria. African Scientist 9: 13-23.

6. El-Assal F, Fol M (2011) Corbicula species (Bivalvia: Veneroida), from the rive Nile in Egypt as bioindicators of pollution. Environmental Pollution Ecological Impacts Health Issues and Management 82-91.

7. Kamaruzzaman BY, MohdZahir MS, Akbar John B, Jalal KCA, Shahbudin, S, et al (2011): Bioaccumulation of some heavy metals by green mussel Perna viridis (Linnaeus, 1758) from Pekan, Pahang, Malaysia. International Journal of Biological Chemistry, 5: 54-60.

8. Bishop JA, Cook LM (1981) Genetic consequences of man-made change Academic Press, London, UK. p209.

9. Klerks PL, Weis JS (1987) Genetic adaptation to heavy metals in aquatic organisms: a review. Environ Pollut 45: 173-205

10. Ibrahim AM, Bishai HM, Khalil MT (1999) Freshwater molluscs of Egypt: publication of National Biodiversity unit, No.10. Egyptian Environmental Affairs Agency, Dept. of Nature protection.

11. Sleem SH, Ali TG (2008) Application of RAPD-PCR in taxonomy of certain freshwater bivalves of genus Caelatura. Global Journal of Molecular Sciences 3: 27-31.

12. Graf DL, Cummings KS (2007) Preliminary review of the freshwater mussels (Mollusca: Bivalvia: Unionoida) of Northern Africa, with an emphasis to the Nile. Journal of the Egyptian German Society of Zoology 53: 89-118. 
Citation: El Assal FM, Sabet SF, Varjabedian KG, Fol MF (2014) Pollution of Freshwater Coelatura species (Mollusca: Bivalvia: Unionidae) with Heavy Metals and its impact on the Ecosystem of the River Nile in Egypt. Int J Waste Resources 4: 163. doi: 10.4172/2252-5211.1000163

13. Williams JD, Warren ML, Cummings KS, Harris JL, Neves RL (1992) Conservation status of freshwater mussels of the United States and Canada. Fisheries 18: 6-22.

14. Hastie LC, Cosgrove PJ, Ellis N, Gaywood MJ (2003) The threat of climate change to freshwater pearl mussel populations. Ambio 32: 40-46.

15. Wang N, Ingersoll CG, Ivey CD, Hardesty DK, May TW, et al. (2010) Sensitivity of early life stages of freshwater mussels (Unionidae) to acute and chronic toxicity of lead, cadmium, and zinc in water. Environ Toxicol Chem 29: 20532063.

16. Ibrahim AM, Aly RH, Kenchington E, Ali TG (2008) Genetic polymorphism among five populations of Pinctada radiata from the Mediterranean coast in Egypt indicated by RAPD-PCR technique. Egyptian Journal of Zoology 50: 467-477.

17. Yousif F, Ibrahim A, Sleem S, El Bardicy S, Ayoub M (2009) Morphologica and genetic analyses of Melanoides tuberculata populations in Egypt. Global Journal of Molecular Sciences, 4: 112-117.

18. Williams JG, Kubelik AR, Livak KJ, Rafalski JA, Tingey SV (1990) DNA polymorphisms amplified by arbitrary primers are useful as genetic markers. Nucleic Acids Res 18: 6531-6535.

19. Pérez T, Albornoz J, Domínguez A (1998) An evaluation of RAPD fragment reproducibility and nature. Mol Ecol 7: 1347-1357.

20. Abdellatif KF, Khidr YA (2010) Genetic diversity of new maize hybrids based on SSR markers as compared with other molecular and biochemical markers. Journal of Crop Science and Biotechnology 13: 139-145.

21. Rohlf FJ (1998) NTSYSpc Numerical taxonomy and multi variate analysis system, version 2.02c. Exeter Software, New York, USA.

22. Jaccard $P$ (1908) Nouvelles recherches sur la distribution florale. Bull Soc Vaudoise Sci Nat 44: 223-270.

23. Sneath PHA, Sokal RR (1973) Numerical taxonomy. Freeman, San Francisco, USA.

24. Murphy VA (1987) Method of determination of Sodium, Potassium, Calcium Magnesium, Chloride, and Phosphate in the rat choroids plexus by Flame Atomic Absorption and Visible Spectroscopy. Anal Biochem 161: 144-151.

25. Johanson CE, Reed DJ, Woodbury DM (1976) Developmental studies of the compartmentalization of water and electrolytes in the choroid plexus of the neonatal rat brain. Brain Res 116: 35-48.

26. Kalfakakour V, Akrida-Demertzi K (2000) Transfer factors of heavy metals in aquatic organisms of different trophic levels 1: 768-786.

27. Rashed MN (2001) Monitoring of environmental heavy metals in fish from Nasser Lake. Environ Int 27: 27-33.

28. World Health Organization (WHO) (1989) Heavy metals-environmenta aspects. Environment Health Criteria.No. 85. Geneva, Switzerland.

29. FAO/WHO (Food and Agriculture Organization of the United Nations/ World Health Organization) (1999) Evaluation of certain food additives and contaminants. Expert Committee on Food Additives. WHO Technical Report Series, No. 884, p7.

30. Haggag AM, Marie MAS, Zaghloul KH (1999) Seasonal effects of the industria effluents on the Nile catfish; Clarias gariepinus. J. Egypt. Ger. Soc. Zool., 28 365-391.

31. Salah El-Deen MA, Khalid HZ, Gamal O, Abo-Hegab S (1999) Concentrations of heavy metals in water sediment and fish in the River Nile in the industria area of Helwan. Egypt. J. Zool. 32: 373-395.

32. Zaghloul KH, Omar WA, Mikhail WZ, Abo-Hegab S (2000) Ecological and biochemical studies on the Nile fish Orechromis niloticus (L.), cultured in different aquatic habitats. Egypt. J. Zool., 34: 379-409.

33. Moraga D, Mdelgi-Lasram E, Romdhane MS, El Abed A, Boutet I, et al. (2002) Genetic responses to metal contamination in two clams: Ruditapes decussatus and Ruditapes philippinarum. Mar Environ Res 54: 521-525.

34. Nadig SG, Lee KL, Adams SM (1998) Evaluating alterations of genetic diversity in sunfish populations exposed to contaminants using RAPD assay. Aquatic Toxicology 43: 163-178.

35. Krane DE, Sternberg DC, Burton GA (1999) Randomly amplified polymorphic DNA profile-based measures of genetic diversity in crayfish correlated with environmental impacts. Environmental Toxicology and Chemistry 18: 504-508.
36. Atienzar FA, Cordi B, Donkin ME, Evenden AJ, Jha AN, et al (2000) Comparison of ultraviolet-induced genotoxicity detected by random ampilified polymorphic DNA with chlorophyll fluorescence and growth in a marine macroalgae, Palmaria palmate. Aquat Toxicol 50: 1-12.

37. Atienzar FA, Venier P, Jha AN, Depledge MH (2002) Evaluation of the random amplified polymorphic DNA (RAPD) assay for the detection of DNA damage and mutations. Mutat Res 521: 151-163.

38. Giantsis IA, Kravva N, Apostolidis AP (2012) Genetic characterization and evaluation of anthropogenic impacts on genetic patterns in cultured and wild populations of mussels (Mytilus galloprovincialis) from Greece. Genet Mol Res 11: 3814-3823.

39. Ortmann AE (1920) Correlation of shape and station in freshwater mussels (naiads) Proceedings of the American Philosophical Society 59: 269-312.

40. Graf DL (1998) Sympatric speciation of freshwater mussels (Bivalvia: Unionoidea): a model. American Malacological Bulletin 14: 35-40.

41. Philippi RA (1848) Abbildungen und Beschreibungen never Oder wenig gekannter conchylien, II and III Kassel.

42. Nevo E, Noy R, Lavie B, Beiles A, Muchtar S (1986) Genetic diversity and resistance to marine pollution. Biological Journal of the Linnean Society 29 139-144.

43. Bickham JW, Smolen MJ (1994) Somatic and heritable effects of environmental genotoxins and the emergence of evolutionary toxicology. Environ Health Perspect 102 Suppl 12: 25-28.

44. Abdul-Aziz KK (2012) The Physiological Status and Genetic Variations of the Bivalve, Pinctada radiata Affected by Environmental Pollution. Research. Journal of Pharmaceutical, Biological and Chemical Sciences 3: 277-291.

45. Yap CK, Cheng WA, Ong CC, Tan SG ( 2013) Heavy Metal Concentration and Physical Barrier are Main causal agents for the Genetic Differentiation of Pera viridis in Peninsular Malaysia. Sains Malaysiana 42: 1557- 1564.

46. Belfiore NM, Anderson SL (2001) Effects of contaminants on genetic patterns in aquatic organisms: a review. Mutat Res 489: 97-122.

47. Coughlan BM, Hartl MGJ, O'Reilly SJ, Sheehan D, Morthersill C, et al (2002) Detecting genotoxicity using the Comet assay following chronic exposure of Manila clam Tapes semidecussatus to polluted estuarine sediments. Mar Pollut Bull 44: 1359-1365.

48. De Wolf H, Blust R, Backeljan, T (2004) The population genetic structure of littorina littorea (Mollusca: Gastropoda) along population gradient in the scheld Estuary the Netherlands using RAPD analysis. Sci. Total Environ 325: 59-69.

49. Liyan Z, Ying $H$, Guangxing $L$ (2005) Using DNA damage to monitor water environment. Chinese J Oceanol Limnol 23: 340-348.

50. Gaikwad SS, Kamble NA (2014) Heavy Metal Pollution of Indian Rivers and its Biomagnifications in the Molluscs. Oct Jour Env Res 2: 67-76.

51. Neeratanaphan L, Sudmoon R, Chaveerach R (2014) Genetic erosion in the freshwater snails filopalodina martensi is affected by lead and cadmium. Applied Ecology and Environmental Research 12: 991- 1001

52. Forni A (1994) Comparison of chromosome aberrations and micronuclei in testing genotoxicity in humans. Toxicol Lett 72: 185-190.

53. Reid TM, Feig DI, Loeb LA (1994) Mutagenesis by metal-induced oxygen radicals. Environ Health Perspect 102 Suppl 3: 57-61.

54. Wong PK (1988) Mutagenicity of heavy metals. Bull Environ Contam Toxicol 40: 597-603.

55. Izquierdo JI, Machado G, Ayllon F, d’Amico V, BalaVallarono E, et al (2003) Assessing pollution in coastal ecosystems: a preliminary survey using the micronucleus test in the mussel Mytilus edulis. Ecotoxicol. Env.Safty 55: 24-29.

56. Baillie JEM, Hilton-Taylor C, Stuart SN (2004) A global species assessment, IUCN red list of threatened species, IUCN, Cambridge, UK. p 1-217.

57. Lydeard C, Cowie RH, Ponder WF, Bogan AE, Bouchet $P$, et al (2004) The global decline of nonmarine mollusks. Bioscience 54: 321-330.

58. Bogan AE (1993) Freswater bivalve extinctions search for a cause (Mollusca: Unionida). Amer Zool 33: 599-609.

59. Ricciardi A, Neves RJ, Rasmussen JB (1998) Impending extinctions of North American freshwater mussels (Unionida) following the zebra mussel (Dreissena polymorpha) invasion. Journal of Animal Ecology 67: 613-619. 
Citation: El Assal FM, Sabet SF, Varjabedian KG, Fol MF (2014) Pollution of Freshwater Coelatura species (Mollusca: Bivalvia: Unionidae) with Heavy Metals and its impact on the Ecosystem of the River Nile in Egypt. Int J Waste Resources 4: 163. doi: 10.4172/2252-5211.1000163

60. Aboul-Dahab HM (2002) Cellular responses of the molluscan host, Unio abyssinicus infected by two new haplosporidian parasites with emphasis on the morphological characteristics of the host haemolymph. Egyptian Journal of Zoology 38: 149-170.

61. Ramadan SA (2003) A comparison of the population structure of the water mite Unionicola tetrafurcatus inside two molluscan hosts from the River Nile, Egypt. Egyptian Journal of Zoology 41: 229-247.

62. Hashmi, MI, Mustafa S, Tariq SA (2002) Heavy metal concentrations in water and tiger prawn (Penaeus monodon) from grow-out farms in Sabah, North Borneo. Food Chemistry 79: 151-156.
63. World Health Organization (WHO) (1996) Guidelines for drinking-water quality,2nd edn Vol.2. Health Criteria and Other Supporting Information. Geneva, Switzerland.

64. World Health Organization(WHO) (2008) Guidelines for drinking-water quality. Geneva, 3rd edn Vol.1. Geneva, Switzerland. 